\title{
Neuroimaging with Radiopharmaceuticals Targeting the Glutamatergic System
}

\author{
Linjing Muªb, Stefanie D. Krämera, Hazem Ahmeda, Stefan Gruber ${ }^{a}$, Susanne Geistlicha, \\ Roger Schibliab, and Simon M. Ametamey ${ }^{\star a}$
}

\begin{abstract}
Radiopharmacy at ETH has worked on the development of novel PET tracers for neuro-, cardiac- and tumor imaging for many years. In this paper, our efforts on targeting the glutamatergic system of the metabotropic glutamate receptor subtype 5 (mGluR5) and the ionotropic $N$-methyl-D-aspartate (NMDA) receptor are summarized. We briefly described the principles of positron emission tomography (PET) tracer development for the central nervous system (CNS) and the radiolabeling methods used in our laboratory. To assess the radioligands, results of in vitro autoradiography, biodistribution, and metabolite studies as well as PET imaging data are discussed. Furthermore, key PET parameters for kinetic modeling and quantification methods are provided. Two mGluR5 PET tracers, $\left[{ }^{11} \mathrm{C}\right] \mathrm{ABP} 688$ and $\left[{ }^{18} \mathrm{~F}\right] \mathrm{PSS} 232$, were translated in our GMP labs and evaluated in human subjects. The newly developed GluN2B PET tracer $\left[{ }^{11} \mathrm{C}\right] \mathrm{Me}$-NB1 is currently being investigated in a first-in-human PET study and several F-18 labeled tracers are being evaluated in non-human primates in which the first-in-class will be translated for human studies.
\end{abstract}

Keywords: Glutamate receptors - GluN2B subunit of the ionotropic NMDA receptor - Metabotropic glutamate receptor subtype 5 (mGluR5) · PET tracer evaluation



Linjing $\mathbf{M u}$ received her $\mathrm{PhD}$ in Chemistry from Nankai University, China in 1996. She worked as a postdoctoral fellow at the University of Basel and Center for Radiopharmaceutical Sciences (CRS) in Switzerland. In 2004, she was appointed team leader for PET chemistry at CRS. She is the Research Head of Radiopharmacy since 2010 and works at both University Hospital and ETH Zurich. Her research interests focus on PET tracer development and the development of new ${ }^{18} \mathrm{~F}$-radiolabeling methods as well as the translation of new PET tracers into the clinic.

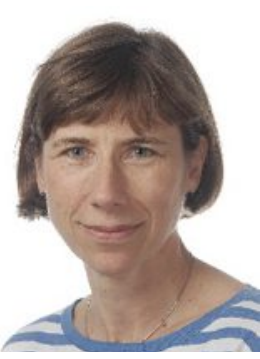

Stefanie D. Krämer is Adjunct Professor for Biopharmacy at the ETH Zurich. She studied Pharmaceutical Sciences at the ETH and received her $\mathrm{PhD}$ in natural sciences from the ETH. She strengthened her expertise in physico-chemical compound characterization and blood-brain barrier models during post-doctoral stays in France and UK. Back at the ETH, she habilitated in 2007 in Biopharmacy and is since 2009 affiliated to the Center for Radiopharmaceutical Sciences (research group of Roger Schibli). Her research interests are the development of PET tracers for imaging immune processes, optimization of fat emulsions for parenteral nutrition, drug-lipid bilayer permeation and PET/pharmacokinetic modeling.

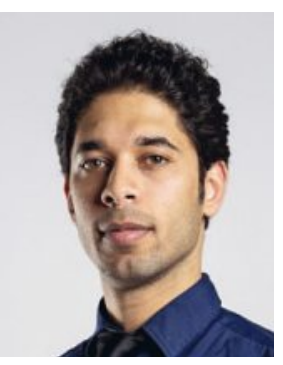

Hazem Ahmed is a post-doctoral researcher at the Center for Radiopharmaceutical Sciences (CRS) of ETH Zurich. He defended his $\mathrm{PhD}$ title at the same institute under the supervision of Prof. Dr. Simon M. Ametamey. His research focused in particular on developing radiofluorinated PET probes for imaging the GluN2B subunit of the NMDA receptors situated inside the mammalian brain as well as developing novel methods of radiolabeling complex biomolecules with fluorine-18. His current research interest is geared towards using brain and heart PET imaging probes to understand the underlying mechanisms of related pathologies.

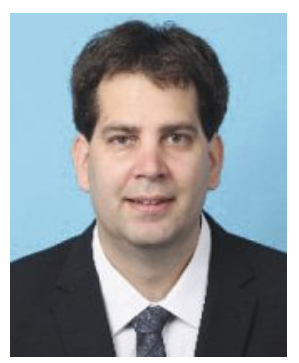

Stefan Gruber received his $\mathrm{MSc}$ and $\mathrm{PhD}$ in chemistry from ETH Zurich. During his $\mathrm{PhD}$ studies in the group of Prof. Paul S. Pregosin, he was working in the area of ruthenium-catalyzed reactions. In 2010, he moved to the University of Basel for a postdoctoral stay in the group of Prof. Andreas Pfaltz, where he was working in the field of asymmetric hydrogenations. From 2013 to 2015, Stefan was a SNSFfunded postdoctoral researcher at the University of Oxford with Prof. Veronique Gouverneur investigating new methods for fluorine-18 labelling of compounds for PET-imaging. In 2016, Stefan returned to Switzerland to take up a position at the Center for Radiopharmaceutical Sciences and since 2019, he is a Senior Scientist at the Institute of Pharmaceutical Sciences at ETH Zurich. 




Susanne Geistlich graduated as Pharmacist from ETH Zurich and joined the Center for Radiopharmaceutical Sciences (CRS) in 2009 after having gained experience in pharmaceutical industry. She obtained the EANM certificate as a radiochemist/radiopharmacist in 2011. She heads the group responsible for translating CRS radiopharmaceuticals from preclinical to clinical use and her team supplies clinical trials with study drugs.



Prof. Dr. Roger Schibli is Full Professor in the Department of Chemistry and Applied Biosciences (ETH Zurich) since 2010, and Laboratory Head at the Paul Scherrer Institute (PSI). He leads the Center for Radiopharmaceutical Sciences (CRS), a joint endeavor between the ETH Zurich, the Paul Scherrer Institute and the University Hospital Zurich. Prof. Schibli studied Chemistry at the University of Basel. His research is directed towards targeted tumor diagnosis and therapy using radiolabeled compounds from 'bench-to-bedside'.

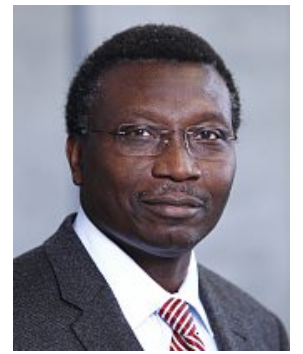

Prof. Simon M. Ametamey earned his doctorate degree in Organic Chemistry from the University of Zurich in 1989 and spent one year as a postdoctoral fellow with Prof. K. Bernhard at Hoffmann La Roche, Basel, Switzerland. In 1991, he joined the Center for Radiopharmaceutical Sciences in Villigen, Switzerland and was appointed group leader in 1995. In 2001, he completed his habilitation in Radiopharmaceutical Chemistry at ETH Zurich and in 2006 was appointed Titular professor. His research work concentrates on the development of PET radioligands for the central nervous system.

\section{Introduction}

The ETH site of the Center for Radiopharmaceutical Sciences (CRS) was set up in 2005. It comprises a cyclotron for radionuclide production, several lead-shielded hoods equipped with manipulators and automated modules in radiolabeling labs for pre-clinical and GMP synthesis, organic chemistry labs, animal facilities and PET/CT scanners for preclinical imaging. Ongoing research activities include target identification, lead finding and optimization, structure-activity relationship studies, radiolabeling with $\mathrm{C}-11$ and F-18. The radiotracer evaluation covers metabolic studies, in vitro autoradiography, in vivo PET imaging and kinetic modelling. The GMP labs enable clinical studies using novel PET tracers, which were developed at CRS or by our academic and industry partners. Much emphasis is devoted to the development of novel PET tracers for molecular imaging receptors, transporters and enzymes, which have implications in neurology, cardiology and oncology. In the past years PET tracers targeting the glutamatergic system, namely the metabotropic glutamate receptor subtype 5 (mGluR5) and GluN2B subunit $N$-methyl-D-aspartate (NMDA) receptor have been developed. ${ }^{[1]}$ This review paper provides a short summary on our research activities on targeting these two central nervous system (CNS) receptors.

\subsection{Positron Emission Tomography Tracer Development for the Central Nervous System}

Positron emission tomography (PET) is a non-invasive, quantitative, nuclear medicine imaging technique, which employs radiation from positron emitting radioisotopes to produce a three-dimensional image of the distribution of radiotracers in vivo. PET tracers are usually administered at a negligible dose without inducing any pharmacological effect. Non-invasive PET imaging can provide information pertaining to target localization and density changes in pathologic conditions, and has proven to be a powerful technique in neurological research. ${ }^{[2]}$ Carbon-11 and fluorine-18 are two commonly used PET radionuclides for imaging the CNS due to their chemical properties and suitable physical half-lives of $20 \mathrm{~min}$ and $110 \mathrm{~min}$, respectively. Criteria for a successful CNS PET tracer are:

- The ligand should be amenable for C-11 or F-18 incorporation. In general, late-stage radiolabeling approaches are favored.

- It should provide strong affinity towards the target $\left(K_{\mathrm{D}}\right.$ in the low nanomolar to subnanomolar range depending on the concentration of target sites $B_{\max }$ ). The binding potential namely $B_{\max } / K_{\mathrm{D}}$ ratio is often used to predict a specific signal in vivo: the higher $B_{\max } / K_{\mathrm{D}}$, the higher the signal-to-noise ratio. ${ }^{[3]}$

- It should display high selectivity; the $B_{\max } / K_{\mathrm{D}}$ for the target should be more than 100-fold higher than for other potential targets.

- It should provide good permeability of the blood-brain barrier (BBB); the logarithmic partition coefficient $(\log P$ ) of CNS PET tracers should be well above 1 to allow their passage across the BBB, but still displaying low nonspecific binding to reduce the signal-to-noise ratio. ${ }^{[4]}$ The recommended $\log P$ range for CNS PET tracers is 1 to 3.5..$^{[5]}$

- It should not be a substrate for BBB efflux transport systems; the $\mathrm{BBB}$ possesses efflux pumps which can prevent compounds from effectively distributing to the brain, of which P-glycoprotein (P-gp) is a key efflux pump. ${ }^{[6]}$ Therefore, a PET tracer should not be a substrate for BBB efflux systems.

- Absence of brain-penetrant radiometabolites; radiometabolites should not be able to cross the BBB as they would increase non-specific signals in the brain and complicate quantification. Besides the above-mentioned criteria, intra- and inter-subject variability should be also considered before clinical translation, as higher variability requires larger sample size studies to delineate alterations between populations.

It should be pointed out that these criteria are recommended guidelines to assist in the selection of potential CNS imaging ligands. They provide no guarantee for the successful development of a PET tracer. Therefore, recently, multiparameter optimization (MPO) has been applied in screening CNS drugs and PET tracers. ${ }^{[7]}$ The additional physico-chemical parameters to be taken into consideration for optimization include lipophilicity, molecular weight, topological polar surface area, number of hydrogen bond donors and $\mathrm{pKa}$ value of a substance.

\subsection{Synthesis of Carbon-11 and Fluorine-18 Labeled Tracers}

Among the many available positron emitting radionuclides, carbon-11 and fluorine-18 are the most often used radioisotopes for brain imaging (Scheme 1). In our laboratory, $\left[{ }^{11} \mathrm{C}\right] \mathrm{CO}_{2}$ or $\left[{ }^{18} \mathrm{~F}\right]$ fluoride can be produced using a Cyclone $18 / 9$ cyclotron (18-MeV; IBA, Belgium) by proton bombardment of a nitrogen gas target $\left({ }^{14} \mathrm{~N}(\mathrm{p}, \alpha){ }^{11} \mathrm{C}\right.$ nuclear reaction) or oxygen-18 enriched water target $\left({ }^{18} \mathrm{O}(\mathrm{p}, \mathrm{n}){ }^{18} \mathrm{~F}\right.$ nuclear reaction $)$, respectively. ${ }^{[8]}$ The simplest and most widely used method for introducing carbon-11 into a pharmaceutical compound is via radiomethylation of an appropriate precursor compound. ${ }^{[9]}$ For that, $\left[{ }^{11} \mathrm{C}\right]$ iodomethane $\left(\left[{ }^{11} \mathrm{C}\right] \mathrm{MeI}\right)$ can be prepared by reduction of $\left[{ }^{11} \mathrm{C}\right] \mathrm{CO}_{2}$ to $\left[{ }^{11} \mathrm{C}\right] \mathrm{CH}_{4}$ employing a nickel catalyst and subsequent gas phase iodination at high temperature $\left(720^{\circ} \mathrm{C}\right)$. For synthetically challenging methylation reactions, $\left[{ }^{11} \mathrm{C}\right]$ MeI can be converted to the more reactive $\left[{ }^{11} \mathrm{C}\right]$ methyl triflate.

The cyclotron-produced $\left[{ }^{18} \mathrm{~F}\right]$ fluoride is in its aqueous form highly hydrated. Therefore, water is usually first removed through trapping the fluoride on an anion exchange cartridge (QMA cartridge) and subsequent elution using potassium carbonate 
$\left(\mathrm{K}_{2} \mathrm{CO}_{3}\right)$ in the presence of Kryptofix $222\left(\mathrm{~K}_{222}\right)$ or tetra-butylammonium hydroxide to form $\left[{ }^{18} \mathrm{~F}\right] \mathrm{KF}-\mathrm{K}_{222}$ or $\left[{ }^{18} \mathrm{~F}\right] \mathrm{TBAF}$, respectively. Further azeotropic drying with acetonitrile affords 'naked' fluoride, which displays increased nucleophilicity and can be used in various alkyl and aromatic nucleophilic substitution reactions. Radiolabeling of electron-rich aromatic rings can be facilitated by copper-mediated fluorination of pinacol boronic ester.[10]
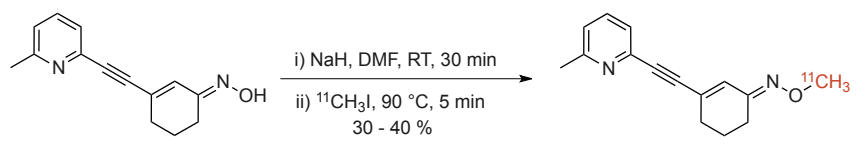

$\left.{ }^{[1} \mathrm{C}\right] \mathrm{ABP} 688$
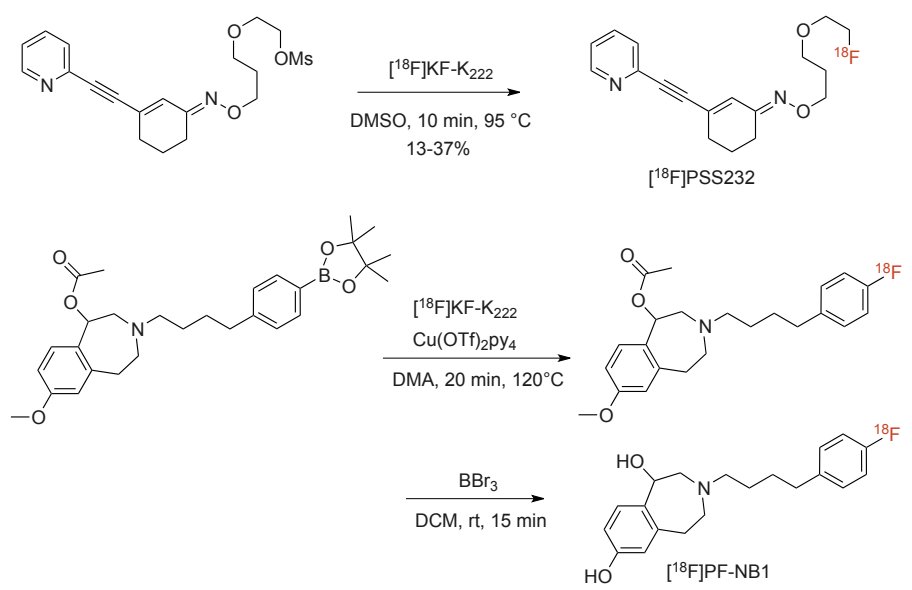

Scheme 1. Synthetic schemes of ${ }^{11} \mathrm{C}$ - and ${ }^{18} \mathrm{~F}$-labeled radiopharmaceuticals for targeting the mGluR5 $\left(\left[{ }^{11} \mathrm{C}\right] \mathrm{ABP} 688\right.$ and $\left.\left[{ }^{18} \mathrm{~F}\right] \mathrm{PSS} 232\right)$ and the GluN2B subunit of the ionotropic NMDA receptor ([18 $\mathrm{F}] \mathrm{PF}-\mathrm{NB} 1)$.

\subsection{Targeting Glutamatergic System with PET}

Glutamate is the major excitatory neurotransmitter in the mammalian CNS, and glutamate receptors (GluR) are implicated in a range of neurological functions. Two distinct groups of GluRs have been identified: ionotropic receptors (iGluR) and metabotropic receptors (mGluR). The vast majority of excitatory neurotransmission is mediated via ligand-gated iGluR of which three major types are currently well-characterized, namely the $\alpha$-amino-3-hydroxy-5-methyl-4-isoazolepropionic acid (AMPA), $N$-methyl-D-aspartate (NMDA) and the kainate receptors. mGluR belong to the superfamily of G-protein-coupled receptors and include eight receptor subtypes, classified into three groups. Group I includes mGluR1 and mGluR5, group II includes mGluR2 and mGluR3, and group III includes mGluR4, mGluR6, mGluR7, and mGluR8. Modulation of iGluR and mGluR has potential for the treatment of psychiatric and neurological diseases such as depression, anxiety, schizophrenia, and Parkinson's disease. PET imaging of glutamate receptors can provide essential information on the function of individual receptors and their variation under physiologic, pathologic and therapeutic conditions. CRS at ETH has worked since many years on the development of radioligands for mGluR5 and GluN2B subunit of the NMDA receptors. Two mGluR5 PET tracers, $\left[{ }^{11} \mathrm{C}\right] \mathrm{ABP} 688$ and $\left[{ }^{18} \mathrm{~F}\right] \mathrm{PSS} 232$, have been evaluated in human subjects, and novel GluN2B PET tracers are on the way to be translated into first-in-human studies (see below).

\section{Metabotropic Glutamate Receptor Subtype 5 (mGluR5)}

The mGluR5 belongs to group I of metabotropic glutamate receptors. It plays a key role in long-term potentiation and increasing evidence indicated that it might be involved in numerous CNS disorders including depression, anxiety, addiction, schizophrenia, Parkinson's disease, and fragile X syndrome.[11]
As such, this receptor is considered as a potential drug target for the treatment of the aforementioned CNS disorders. A number of noncompetitive mGluR5 ligands have been developed during the past years. 2-Methyl-6-(phenylethynyl)pyridine (MPEP) and 3-[(2-methyl-1,3-thiazol-4-yl)ethynyl]pyridine (MTEP) are the first potent and selective noncompetitive mGluR5 antagonists. [12] Many succeeding compounds have been developed based on the core structures of MPEP and MTEP. The relatively high expression levels of mGluR5 in distinct brain regions (e.g. hippocampus, striatum, amygdala, and cortex) and the availability of high affinity ligands render this protein a good target for PET imaging. $\left[{ }^{11} \mathrm{C}\right]$ ABP688 is the first successful PET tracer for imaging mGluR5 in human subjects. ${ }^{[13]}$ The radioactivity distribution pattern was in line with the mGluR5 expression levels in the human brain mentioned above. Using $\left[{ }^{11} \mathrm{C}\right] \mathrm{ABP} 688$, downregulation of mGluR5 has been demonstrated in the brains of smokers and patients suffering from depression, ${ }^{[14]}$ while sleep-deprived subjects showed a global increase in mGluR5 availability when compared to normal healthy controls. ${ }^{[15]}$ More studies are planned in patients with Parkinson's disease, multiple sclerosis and epilepsy. Although $\left[{ }^{11} \mathrm{C}\right] \mathrm{ABP} 688$ was employed in many clinical studies because of its superior pharmacokinetic characteristics, its widespread use is limited due to the short physical half-life of carbon-11 $\left(t_{1 / 2}=20\right.$ $\mathrm{min})$. This prompted us to develop a fluorine-18 labeled analogue which allows distribution of the radiotracer to PET centers lacking an on-site cyclotron. This article provides a summary of our efforts towards the development of fluorine-18 labeled mGluR5 PET tracers and their in vitro and in vivo evaluations (Fig. 1).

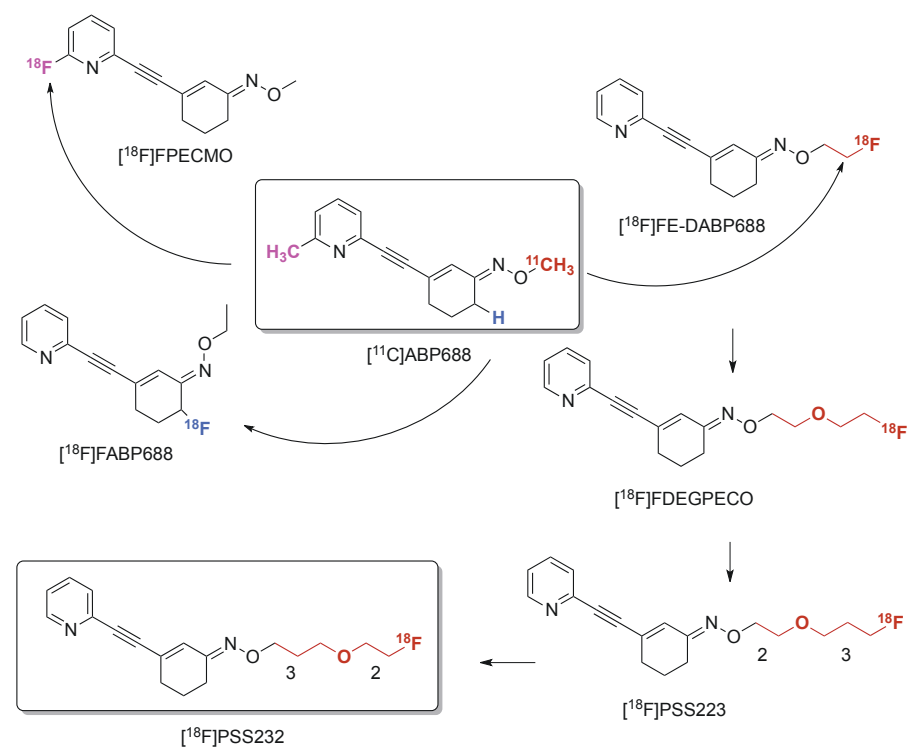

Fig. 1. Strategies to develop F-18 labeled ABP688 analogues.

\subsection{Replace Methyl Group with Fluorine Atom of the Pyridine Ring}

$\left[{ }^{18} \mathrm{~F}\right] \mathrm{FPECMO}$ was synthesized in a one-step reaction sequence by reacting $\left[{ }^{18} \mathrm{~F}\right] \mathrm{KF}-\mathrm{K}_{222}$ complex with (E)-3-((6-bromopyridin2-yl)ethynyl)cyclohex-2-enone $O$-methyl oxime in dry DMSO. Despite all the promising in vitro results of optimal lipophilicity $(\log \mathrm{D}=2.1)$, a $K_{\mathrm{i}}$ value of $3.6 \mathrm{nM}$ and high activity accumulation in mGluR5-rich rat brain regions, a rapid defluorination was observed in rat brain in vivo. Further studies with this tracer were consequently abandoned (Fig. 1). ${ }^{[16]}$

\subsection{Replace Hydrogen by Fluorine Atom on the Cyclohexane Ring}

Among five synthesized ABP688 derivatives with fluorine atom at the $\alpha$-position of the oxime ether double bond, the ethyl 
oxime ether (Z)-FABP688, which not only showed a desired $K$ value of $5.7 \mathrm{nM}$ but also a clogP of 2.3, was selected for radiolabeling with F-18. However, the synthesis of the tosylate precursor for radiolabeling revealed a stereochemical preference for the $E$-isomer of the $\alpha$-hydroxy derivative which prompted us to prepare $(E)-\left[{ }^{18} \mathrm{~F}\right] \mathrm{FABP} 688$ (Fig.1). The $K_{\mathrm{i}}$ value for this compound was determined as $31 \mathrm{nM}$, which is $c a$. 6 -fold less potent than its $Z$-form. Although specific signal was observed in in vitro autoradiography studies, ${ }^{[17]}$ the suboptimal affinity and the challenging chemistry prevented further evaluation on this type of structure.

\subsection{Replace the Methyl Group of Oxime Ether with Fluorinated Alkyl Chain}

FE-DABP688 was obtained by replacing the methyl group of oxime ether with fluoroethyl and exhibited a $K_{\mathrm{D}}$ value of $1.6 \mathrm{nM}$. Although the obtained PET image quality of $\left[{ }^{18} \mathrm{~F}\right] \mathrm{FE}-\mathrm{DABP} 688$ was similar to that of $\left[{ }^{11} \mathrm{C}\right] \mathrm{ABP} 688,\left[{ }^{18} \mathrm{~F}\right] \mathrm{FE}-\mathrm{DABP} 688$ displayed unfavorable pharmacokinetics in the anesthetized rat with a fast washout from the forebrain resulting in a relatively short-lived signal. ${ }^{[18]}$ Consequently, $\left[{ }^{18} \mathrm{~F}\right] \mathrm{FE}-\mathrm{DABP} 688$ was not exploited further (Fig. 1).

Changing the methyl group at the oxime functionality by different fluorinated aromatic substituents resulted in moderate binding affinities towards mGluR5.[19] Therefore, more efforts were placed on the synthesis of fluorinated alkyl ABP688 derivatives. Prolongation of the alkyl linker of FE-DABP688 resulted in three compounds named FDEGPECO, PSS223 and PSS232 (Fig. 1). All of them revealed high affinity towards mGluR5, indicating alkyl substituents at the oxime functionality are well tolerated (Fig. 2). $\left[{ }^{18} \mathrm{~F}\right]$ FDEGPECO was produced in a single high-yielding radiochemical step. Target specificity was confirmed by in vitro autoradiography and in vivo PET studies. ${ }^{[20]}$ Although quantification of mGluR5 was possible, image quality suffered from high background radioactivity (Fig. 2).

PSS223 was designed with the aim to increase the lipophilicity of the ligand, in which the side chain was extended by one methylene group. The experimentally determined $\log D$ value of $\left[{ }^{18} \mathrm{~F}\right] \mathrm{PSS} 223$ was 1.9 , which is $0.2 \log$ units higher than that of $\left[{ }^{18} \mathrm{~F}\right]$ FDEGPECO, as expected. ${ }^{[19,21]}\left[{ }^{18} \mathrm{~F}\right] \mathrm{PSS} 223$ showed a heterogeneous distribution on rat brain slices with the highest accumulation in mGluR5-rich brain regions (e.g. hippocampus, striatum, and cortex). Its specificity and selectivity towards mGluR5 was confirmed by using excess concentrations of mGluR5 and mGluR1 blockers. However, $\left[{ }^{18}\right.$ F $]$ PSS223 was significantly metabolized by rat liver microsomal enzymes and to a lesser extent by human liver microsomes. In vivo PET imaging showed high radioactivity in the skull and jaws, and a weak accumulation in the rat brain (Fig. 2), ${ }^{[21]}$ indicating rapid $\left[{ }^{18} \mathrm{~F}\right]$ defluorination in vivo.

The difference in susceptibility for defluorination between $\left[{ }^{18} \mathrm{~F}\right]$ PSS223 and $\left[{ }^{18} \mathrm{~F}\right]$ FDEGPECO was attributed to the $\beta$-heteroatom effect, ${ }^{[22]}$ as the primary aliphatic ${ }^{18} \mathrm{~F}$-atoms in a $\beta$-position to heteroatom $\left(\right.$ e.g. $\left.\left[{ }^{18} \mathrm{~F}\right] \mathrm{FCH}_{2} \mathrm{CH}_{2} \mathrm{OR}\right)$ are found to be more stable than those at the $\gamma$-position $\left(\left[{ }^{18} \mathrm{~F}\right] \mathrm{FCH}_{2} \mathrm{CH}_{2} \mathrm{CH}_{2} \mathrm{OR}\right) .{ }^{[23]}$ Changing the oxygen atom located between the ethylene and the fluoropropyl moieties with the $\mathrm{CH}_{2}$ group of the right side of $\left[{ }^{18} \mathrm{~F}\right] \mathrm{PSS} 223$ (Fig. 1) gave rise to $\left[{ }^{18} \mathrm{~F}\right] \mathrm{PSS} 232$. $\left[{ }^{18} \mathrm{~F}\right] \mathrm{PSS} 232$ revealed improved in vitro and in vivo stabilities. ${ }^{[1 \mathrm{e}, 24]}$ The specificity of $\left[{ }^{18} \mathrm{~F}\right] \mathrm{PSS} 232$ was confirmed in in vitro autoradiography on rat brain slices and in vivo PET images. $\left[{ }^{18} \mathrm{~F}\right] \mathrm{PSS} 232$ turned out to be an ideal F-18 labeled PET tracer for imaging mGluR5 in rat brain (Fig. 2 ). Image data were reproducible in test-retest studies with a variability ranging from $6.8 \%$ to $8.2 \%$. An extended single-dose toxicity study in Wistar rats showed no compound-related toxic effects. ${ }^{[1 e]}$ Encouraged by the promising preclinical data obtained with $\left[{ }^{18} \mathrm{~F}\right] \mathrm{PSS} 232$ in rodents, the radiochemistry was established in our GMP labs, and the results of first-in-human studies were published in 2018. ${ }^{[1 f]}$ The brain uptake pattern of [ $\left.{ }^{18} \mathrm{~F}\right] \mathrm{PSS} 232$ was similar to that of its analog $\left[{ }^{11} \mathrm{C}\right] \mathrm{ABP} 688$, and matched the distribution pattern of mGluR5. The kinetics of $\left[{ }^{18} \mathrm{~F}\right] \mathrm{PSS} 232$ followed a two-tissue compartment model, as seen for many neuroreceptor PET tracers. We hope that this new fluorinated version of ABP688 will find a wider application in clinical studies in the near future. Initial studies using $\left[{ }^{18} \mathrm{~F}\right] \mathrm{PSS} 232$ to measure mGluR5 expression levels in LPS-induced murine neuroinflammation model showed increased mGluR5 expression in neuroinflammatory mouse brain. ${ }^{[25]}$ In autoradiographic studies, levels of mGluR5 in human $\mathrm{AD}$ and amyotrophic lateral sclerosis (ALS) postmortem brain were also found to be several-fold higher compared to control brains. ${ }^{[25]}$ These results suggest that mGluR5 might be a useful target to consider for neuroinflammatory diseases and that diagnosis and the therapy monitoring of AD and ALS patients could be accomplished via mGluR5 imaging.

\section{GluN2B Subunit of the $\mathbf{N}$-Methyl-D-aspartate Receptor}

The NMDA receptor is one of three glutamatergic ion channel types that are ubiquitously expressed in the CNS, and are requisite in synaptic transmission, plasticity and higher cognitive functions. ${ }^{[26]}$ NMDA receptors are heterotetrameric assemblies of three distinct subunits, namely GluN1-3. The identity of these subunits are further complexed by splice variants (GluN1a-h) and different encoding genes (GluN2A-D and GluN3A-B). For NMDA to be fully functional, it requires the obligatory presence of two GluN1 subunits in addition to two GluN2 or GluN3 subunits. ${ }^{[27]}$ The presence of a particular GluN2 subunit governs the function of the receptor within a unique spatiotemporal expression framework. Extrasynaptic GluN2B subunit-containing NMDA receptor gathered much attention owing to their involvement in a plethora of neurological pathologies such as Alzheimer's disease, Parkinson's disease, depression, stroke and schizophrenia. ${ }^{[28]}$ Consequently, contemporary therapeutic targeting approaches steered away from non-selective NMDA modulators, and focused on subunit-selective modulators, with GluN2B subunitcontaining NMDA receptor being the most exploited. In paral-
Fig. 2. PET/CT images of $\left[{ }^{11} \mathrm{C}\right]$ ABP688 and its fluorinated derivatives $\left[{ }^{18} \mathrm{~F}\right]$ FDEGPECO, $\left[{ }^{18} \mathrm{~F}\right]$ PSS223 and $\left[{ }^{18} \mathrm{~F}\right] \mathrm{PSS} 232$ averaged from 0-40 min p.i. in rat brain (brain region indicated by red circle). Binding affinities were determined by using rat brain membranes, for compound PSS232, the $I C_{50}$ value was $1.1 \mathrm{nM}$ for human mGluR5 using $\left[{ }^{3} \mathrm{H}\right] \mathrm{ABP} 688$ as the radioligand. Shake-flask method was used to determine the distribution coefficients $(\log D)$ at $\mathrm{pH} 7.4$.

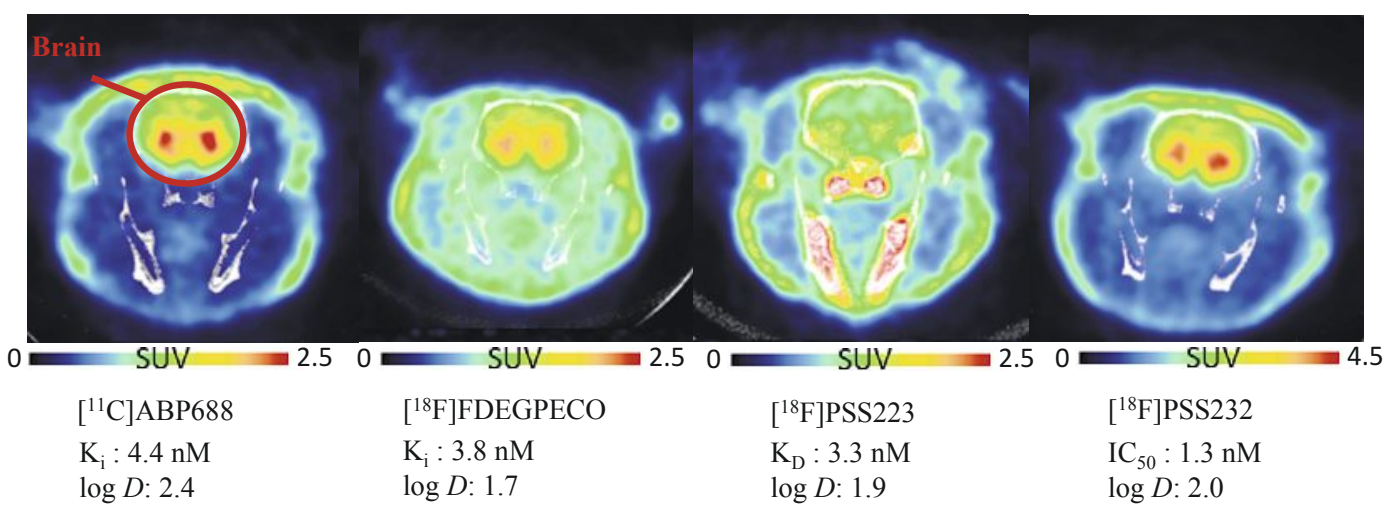


lel, rigorous efforts have been made over the last two decades to introduce a clinically validated PET tracer for imaging GluN2B subunit-containing NMDA receptor to no avail. Major challenges comprised brain radiometabolites, considerable off-target binding, low brain uptake and brain uptake inconsistent with known GluN2B expression profile. ${ }^{[29]}$ Our group has been active in developing PET radioligands for imaging GluN2B subunit-containing NMDA receptor for almost a decade now. We have explored the chemical space pertaining to 2,3,4,5-tetrahydro- $1 H$-3-benzazepine and 6,7,8,9-tetrahydro-5H-benzo[7]annulen-7-amine derivatives..$^{[1 \mathrm{a}-\mathrm{d}, \mathrm{g}]}$ These two classes were comprehensively investigated by Wünsch and co-workers as therapeutic agents.[30] We utilized two key measures to perform preliminary screening of various compounds stemming out of these two classes. One measure involves determining the affinity of the ligand in question towards rat and/or human GluN2B subunit-containing NMDA receptors using competitive binding assays. The second measure utilizes the same approach to investigate the off-target binding of the developed ligands, mainly towards sigma-1 receptors ( $\sigma 1 \mathrm{Rs})$, and to a lesser extent $\sigma 2 \mathrm{Rs}$. The $\sigma 1 \mathrm{R}$ is an endoplasmic reticulum-embedded, ligand-regulated molecular chaperone that regulates the activity of NMDA.[31] Concomitantly, the $\sigma 1 \mathrm{R}$ bears a binding site that is highly similar to the ifenprodil-binding site at the interface of GluN2B and GluN1 subunits that confers subunit-selectivity to GluN2B subunit targeting ligands. Such a similarity further increases the magnitude of complexity associated with the development of GluN2B PET imaging tracers. The first benzazepine-based PET ligand reported by our group for the imaging of GluN2B subunit-containing NMDA receptors was $\left[{ }^{11} \mathrm{C}\right] \mathrm{Me}-\mathrm{NB} 1$, a 2,3,4,5-tetrahydro- $1 \mathrm{H}$-3-benzazepin-1-ol derivative (Fig. 3). ${ }^{[1 \mathrm{~g}]}$ In this preliminary breakthrough work, Me-NB1 $\left(K_{\mathrm{i}}(\right.$ GluN2B $)=5.4 \mathrm{nM}, K_{\mathrm{i}}(\sigma 1 \mathrm{R})=182 \mathrm{nM}$, and $K_{\mathrm{i}}$ $\left.(\sigma 2 \mathrm{R})=54^{[30 \mathrm{a}]}\right)$ was labeled with carbon-11 using $\left[{ }^{11} \mathrm{C}\right] \mathrm{MeI}$, and investigated in in vitro autoradiographic experiments using brain slices from wild-type and $\sigma 1 \mathrm{R}$-knockout mice. While no significant differences were detected in tracer accumulation between wild-type and $\sigma 1 \mathrm{R}-\mathrm{knock}$ out brain slices, specificity and selectivity of $\left[{ }^{11} \mathrm{C}\right] \mathrm{Me}-\mathrm{NB} 1$ binding were confirmed using eliprodil, a GluN2B subunit-containing NMDA antagonist and (+)-pentazocine, a $\sigma 1 \mathrm{R}$ ligand. Encouraged by these results, $\left[{ }^{11} \mathrm{C}\right]$ Me-NB1 was evaluated in Wistar rats using PET, blocking and displacement experiments as well as PET kinetic modeling. At the time, $(+)$-pentazocine reduced the tracer brain uptake of $\left[{ }^{11} \mathrm{C}\right]$ Me-NB1 thereby supporting the notion of $\sigma 1 \mathrm{R}-\mathrm{NMDA}$ crosstalk. In a later report from our group by Haider and co-workers, it was revealed that a tightrope walk between GluN2B subunitcontaining NMDA receptors and $\sigma 1$ Rs affinities exists which is heavily dictated by the enantiomeric form of $\left[{ }^{11} \mathrm{C}\right] \mathrm{Me}-\mathrm{NB} 1 .{ }^{[1 \mathrm{c}]} \mathrm{In}$ in vitro autoradiography, a heterogeneous accumulation of $(R)$ $\left[{ }^{11} \mathrm{C}\right] \mathrm{Me}-\mathrm{NB} 1$ mirrored the known expression pattern of GluN2B subunit-containing NMDA receptors in the forebrain regions comprising the cortex, striatum, thalamus and hippocampus. The specificity and selectivity were established by using a wider variety of GluN2B subunit-containing NMDA blockers (CERC-301, EVT-101 and CP-101,606) and $\sigma 1 \mathrm{R}$ ligands (SA4503, fluspidine and (+)-pentazocine). Importantly, $(R)-\left[{ }^{11} \mathrm{C}\right] \mathrm{Me}-\mathrm{NB} 1$ displayed a consistent dose-response profile with escalating doses of eliprodil in vivo, whereas $(S)$ - $\left[{ }^{11} \mathrm{C}\right] \mathrm{Me}-\mathrm{NB} 1$ exhibited specific binding predominantly towards $\sigma 1 \mathrm{R}$. $(R)-\left[{ }^{11} \mathrm{C}\right] \mathrm{Me}-\mathrm{NB} 1$ is currently being assessed in a first-in-human PET studies. Nonetheless, the foremost inherent drawback of this tracer is the short physical half-life of carbon-11 (physical half-life $=20 \mathrm{~min}$ ), which hampers its utility in PET centers lacking an on-site cyclotron. The development of a fluorine-18 (physical half-life $=110 \mathrm{~min}$ ) analogue would resolve the aforementioned drawback, thereby realizing the satellite distribution concept, and simultaneously offering higher image resolution. ${ }^{[32]}$
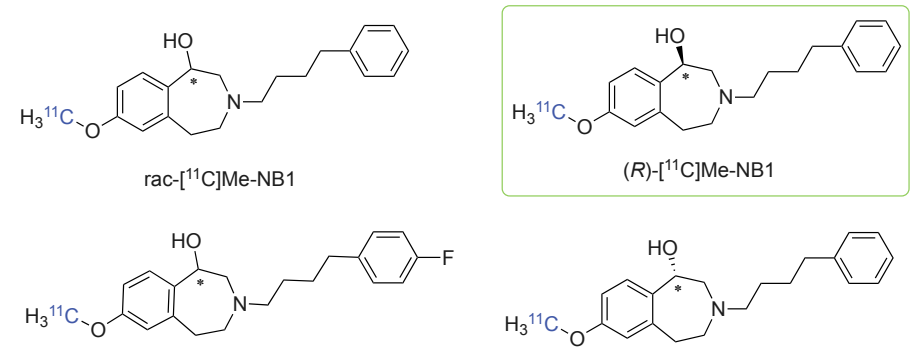

(R)-[11 C]PF-Me-NB1)

(S)-[11C]PF-Me-NB1



$(R)-\left[{ }^{11} \mathrm{C}\right] \mathrm{OF}-\mathrm{Me}-\mathrm{NB} 1$ (S) $-\left[{ }^{11} \mathrm{C}\right] \mathrm{OF}-\mathrm{Me}-\mathrm{NB} 1$



(S) $-\left[{ }^{11} \mathrm{C}\right] \mathrm{Me}-\mathrm{NB} 1$



$(R)-\left[{ }^{18} \mathrm{~F}\right] \mathrm{OF}-\mathrm{Me}-\mathrm{NB} 1$
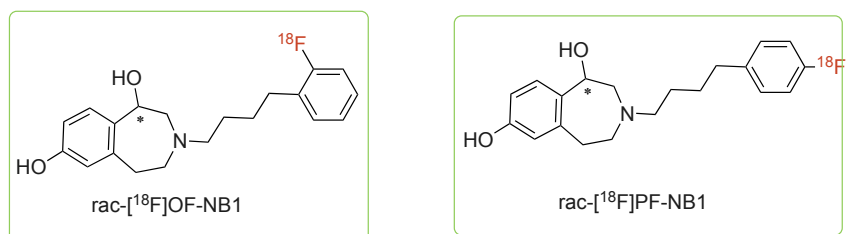

Fig. 3. Structures of developed fluorinated and non-fluorinated radioligands based on the 2,3,4,5-tetrahydro-1 $\mathrm{H}$-3-benzazepine structural class developed in our group. In the green boxes are highlighted the most promising PET ligands that possess potential for clinical translation. (R)- $\left[{ }^{11} \mathrm{C}\right] \mathrm{Me}-\mathrm{NB} 1$ is currently being investigated in a first-in-human PET study.

In 2018, we tackled this challenge and evaluated four different fluorinated analogues by in vitro autoradiography. ${ }^{[1 \mathrm{~d}]}(R)-\left[{ }^{18} \mathrm{~F}\right]$ OF-Me-NB1 emerged as the first fluorinated analogue from the structural class of 2,3,4,5-tetrahydro-1H-3-benzazepin-1-ols for imaging the GluN2B subunit. For the radiosynthesis of $(R)-\left[{ }^{18} \mathrm{~F}\right]$ OF-Me-NB1, we harnessed the copper-mediated radiofluorination of boronic esters, followed by the cleavage of an acetyl protecting group using basic conditions. ${ }^{[33]}$ Later we performed structure-affinity relationship studies and developed $\left[{ }^{18} \mathrm{~F}\right] \mathrm{PF}-$ NB1. This tracer was evaluated in Wistar rats and $\sigma 1 \mathrm{R}-$ knockout mice (Fig. 4). ${ }^{[1 \mathrm{a}]} \mathrm{A}$ remarkable characteristic of $\left[{ }^{18} \mathrm{~F}\right] \mathrm{PF}-\mathrm{NB} 1$ is its slow in vivo brain kinetics relative to earlier tracers. In most recent work, we reported the ortho-analogue, $\left[{ }^{18} \mathrm{~F}\right] \mathrm{OF}-\mathrm{NB} 1$, as the firstin-class successor of $\left[{ }^{18} \mathrm{~F}\right] \mathrm{PF}-\mathrm{NB} 1$, with higher uptake in GluN2B subunit-containing NMDA-rich brain regions in Wistar rats determined in ex vivo biodistribution studies. The potential of imaging the GluN2B subunit was further assessed in cortical brain samples from ALS patients and healthy controls via autoradiography studies. ${ }^{[1 b]}$ The presence of radiometabolites in the brain by means of ex vivo metabolite studies could be excluded. Additionally, we showed the utility of all the tracers through receptor occupancy studies with the GluN2B subunit-containing NMDA antagonists, eliprodil and CP-101,606. In collaboration with Yale University PET Center, the $(R)$ - and $(S)$-enantiomers of $\left[{ }^{18} \mathrm{~F}\right] \mathrm{OF}-\mathrm{NB} 1,\left[{ }^{18} \mathrm{~F}\right]$ OF-Me-NB1 and $\left[{ }^{11} \mathrm{C}\right] \mathrm{Me}-\mathrm{NB} 1$ were assessed in non-human primates. ${ }^{[34]}$ We are currently preparing the documents for a firstin-human PET study. The successful outcome of this study will allow us to validate the radioligand for imaging GluN2B subunitcontaining NMDA in different neuropathologies.

\section{Quantification Methods, from SUV to Kinetic Modeling}

PET is a quantitative imaging method. The reconstructed images can directly be scaled to $\mathrm{Bq} / \mathrm{cm}^{3}$. Normalization for the administered activity, itself normalized to body weight (Bq/g), and 


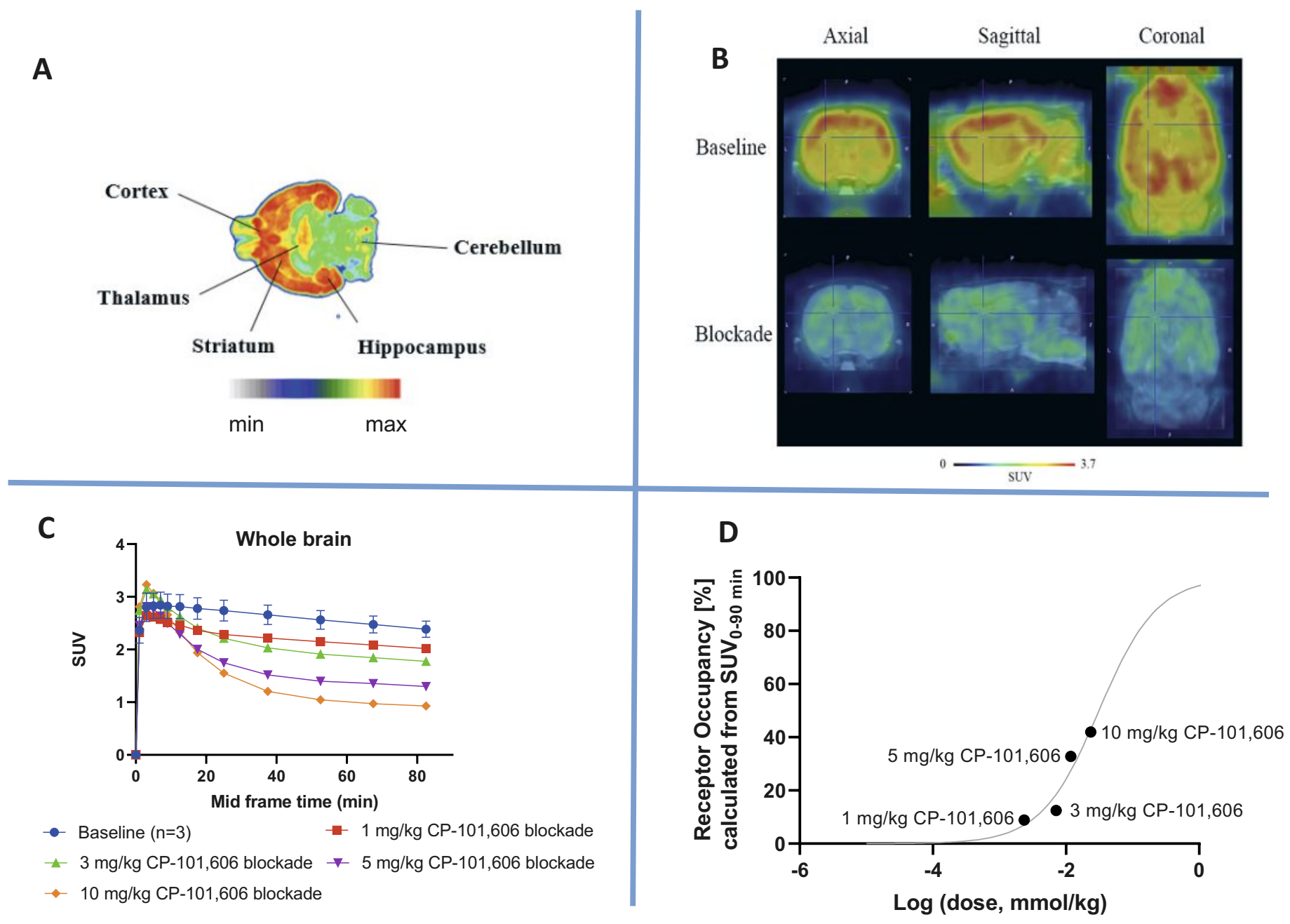

Fig. 4. Typical in vitro autoradiograms, baseline and blockade PET images, whole brain time-activity curves and receptor occupancy plot of one of the promising radiofluorinated PET radioligands, $\left[{ }^{18} \mathrm{~F}\right] \mathrm{PF}-\mathrm{NB} 1$, developed by our group for imaging the GluN2B subunit of the NMDA receptor. A) An autoradiogram of $\left[{ }^{18} \mathrm{~F}\right] \mathrm{PF}-\mathrm{NB} 1$ obtained from rat coronal brain sections where accumulation of the tracer is observed in GluN1/GluN2B rich regions comprising cortex, hippocampus, striatum and thalamus. B) Baseline and blockade $(10 \mathrm{mg} / \mathrm{kg} \mathrm{CP}-101,606)$ in vivo PET images (30-90 min averaged) of the Wistar rat brain superimposed on an MRI template (PMOD). The color bar denotes standardized uptake value (SUV). C) Corresponding time-activity curves of $\left[{ }^{18} \mathrm{~F}\right] \mathrm{PF}-\mathrm{NB} 1$ presented as SUVO-90 min under baseline and blockade conditions with escalating doses of the GluN1/GluN2B antagonist CP-101,606. D) Calculated from the SUV0-90 min, the receptor occupancy was plotted and the CP-101,606 dose required to occupy $50 \%$ of the receptors in vivo (D50) was found to be $31 \mu \mathrm{mol} / \mathrm{kg}$. Adapted with permission from Ahmed et al. Journal of Medicinal Chemistry 2019. Copyright 2019 American Chemical Society.

assuming $1 \mathrm{~g}$ tissue corresponds to $1 \mathrm{~cm}^{3}$, reveals the SUV as a dimensionless parameter. If the applied activity distributed evenly throughout the organism and no activity was excreted the SUV equals to 1. SUV is time-dependent as seen in Fig. 4C but can be averaged over a defined time window to result in an individual parameter, such as SUV averaged from 0 to 90 min after injection used in Fig. 4D. SUV not only depends on the target density and availability for tracer binding, but on many additional factors. These are in particular the kinetics of the tracer in blood plasma, which depends on tracer distribution in the whole body, tracer excretion, metabolism and binding to plasma proteins. The influence of these factors can be excluded by kinetic modeling with the tracer plasma concentration-time curve, called input function. Mechanistic models can be fitted to the input function and image data. PET tracers for neuroreceptors often follow the two-tissue compartment model shown in Fig. 5.

In the two-tissue compartment model shown in Fig. $5, K_{1}$ represents the clearance term from plasma to tissue. It maximally reaches the value of plasma (or blood) flow. Depending on the tracer, it may even be used to estimate regional blood flow. The ratio $K_{1} / k_{2}$ equals the distribution volume (normalized to tissue volume) of non-displaceable (nonspecifically distributed) tracer. At equal steady state concentrations in plasma and tissue, $K_{1} / k_{2}$ equals 1 . The rate constants $k_{3}$ and $k_{4}$ depend on the interaction between the tracer and its target and, importantly, $k_{3}$ on target density in addition. The ratio $k_{3} / k_{4}$ defines the distribution volume between displaceable (specifically bound) and non-displaceable

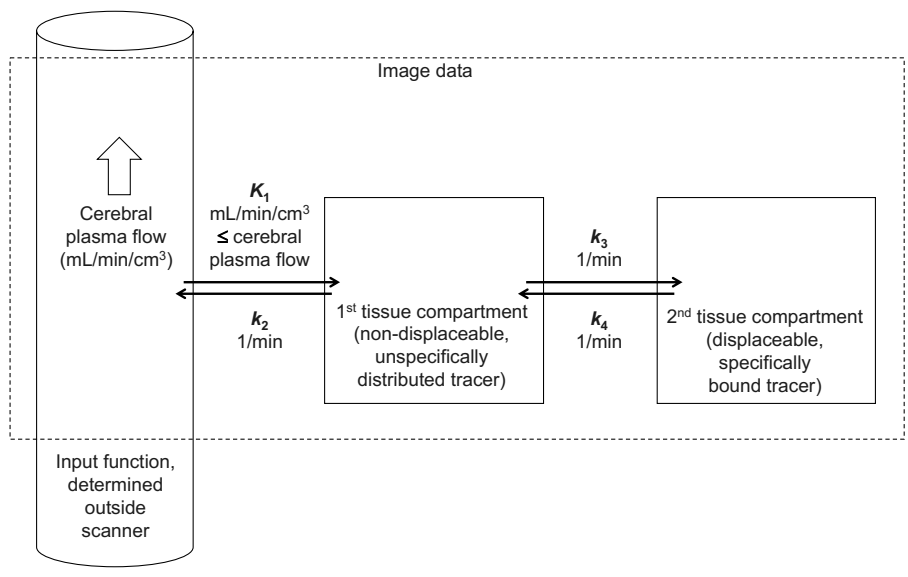

Fig. 5. Two-tissue compartment model for the kinetic analysis in neuroreceptor PET. 
(nonspecifically distributed) tracer. The volume of distribution of total tracer $\left(V_{\mathrm{T}}\right)$ equals $K_{1} / k_{2} \times\left(1+k_{3} / k_{4}\right)$.

The recording of an input function requires an arterial catheter. In preclinical imaging with rodents, we even apply an arteriovenous shunt. ${ }^{[35]}$ The blood is guided through a dedicated coincidence counter. This invasive technique is not intended for routine scans but is the gold standard to characterize the kinetics. Based on the modeling with an input function, alternative, non-invasive quantification models can be defined for a new tracer. For neuro-receptor imaging, these are ideally reference tissue models where a brain region with low or absent target (reference region) can replace the input function. At steady state, when distribution is equilibrated and tissue activity ratios become constant, the activity ratios between regions of interest and the reference region (distribution volume ratio, DVR) approach $1+k_{3} / k_{4}$ (Fig. 5). The respective results can be averages for whole brain or individual brain regions or may be calculated for each image voxel, allowing to generate PET images for individual model parameters such as $K_{1}$ or DVR.

We performed kinetic modeling with $\left[{ }^{18} \mathrm{~F}\right] \mathrm{PSS} 232$ in rats ${ }^{[35]}$ and human volunteers ${ }^{[1 \mathrm{f}]}$ and for $\left[{ }^{11} \mathrm{C}\right] \mathrm{Me}-\mathrm{NB} 1$ in rats. ${ }^{[1 \mathrm{~g}]}$ The modeling with an arterial input function confirmed that tracer activity in the brain follows two-tissue compartment models for both tracers, independent of the species. Fig. 6 shows $\left[{ }^{18} \mathrm{~F}\right]$ PSS232 brain PET images of a volunteer. The upper row shows the DVR, calculated with cerebellum as the reference tissue. DVR is a robust parameter as any variability in blood radioactivity is cancelled out as long as the region of interest and the reference region have the same perfusion (same input function). DVR is, therefore, frequently used in quantitative PET if a reference region can be defined. ${ }^{[14]}$ The lower row in Fig. 6 shows the activity averaged from $45-90 \mathrm{~min}\left(\mathrm{kBq} / \mathrm{cm}^{3}\right)$, when distribution is equilibrated (steady state is reached). As expected at steady state, the averaged activity shows the same pattern as the DVR. However, the absolute numbers $\left(\mathrm{kBq} / \mathrm{cm}^{3}\right)$ depend on the activity dose and the chosen time window.

\section{Conclusion}

We have made great strides in developing PET radioligands for imaging the mGluR5 subtype of the metabotropic receptors. Of the two clinically established mGluR5 radioligands, $\left[{ }^{11} \mathrm{C}\right]$ ABP688 and $\left[{ }^{18} \mathrm{~F}\right] \mathrm{PSS} 232$ developed by our group, $\left[{ }^{11} \mathrm{C}\right] \mathrm{ABP} 688$ has found a widespread use in clinical PET studies since the first human study. $\left[{ }^{18} \mathrm{~F}\right] \mathrm{PSS} 232$ will presumably replace $\left[{ }^{11} \mathrm{C}\right] \mathrm{ABP} 688$ in the near future given its logistic advantages. Much progress has also been made for PET radioligands for imaging the ionotropic NMDA receptor for human application. The ongoing preclinical and first-in-human PET studies with our benzazepine-based PET radioligands will hopefully soon shed light on the utility of these radioligands for imaging the GluN2B subunits of the NMDA receptor. A successful GluN2B PET radioligand would allow the non-invasive characterization of numerous CNS disorders and the determination of appropriate doses of drugs targeting the GluN2B as was similarly done for other established CNS PET radioligands.

\section{Acknowledgements}

The authors thank Dr. Adrienne M. Herde, Dr. Ahmed Haider, Dr. Selena M. Sephton for their scientific contribution; Mrs. Claudia Keller and Mr. Bruno Mancosu for their technical support. Translational research with PSS232 has been supported by the Technology Transfer Project of the Personalized Health and Related Technology (PHRT) initiative of the ETH Domain (PHRT-512); NMDA research was supported by the Swiss National Science Foundation Grant Nos. 310030E160403/1 and 310030E_182872/1.

Received: August 9, 2020

[1] a) H. Ahmed, A. Haider, J. Varisco, M. Stankovic, R. Wallimann, S. Gruber, I. Iten, S. Häne, A. Müller Herde, C. Keller, R. Schibli, D. Schepmann, L. Mu, B. Wünsch, S. M. Ametamey, J. Med. Chem. 2019, 62, 9450, https://doi.org/10.1021/acs.jmedchem.9b00812; b) H. Ahmed, R. Wallimann, A. Haider, V. Hosseini, S. Gruber, M. Robledo, T. A. N. Nguyen, A. M. Herde, I. Iten, C. Keller, V. Vogel, R Schibli, B. Wünsch, L. Mu, S. M. Ametamey, J. Nucl. Med. 2020 , https://doi.org/10.2967/jnumed.120.246785; c) A. Haider, A. M. Herde, S. D. Krämer, J. Varisco, C. Keller, K. Frauenknecht, Y. P. Auberson, L. Temme, D. Robaa, W. Sippl, R. Schibli, B. Wünsch, L. Mu, S. M. Ametamey, J. Nucl. Med. 2019, 60, 1167, https://doi.org/10.2967/jnumed.118.221051; d) A. Haider, I. Iten, H. Ahmed, A. M. Herde, S. Gruber, S. D. Krämer, C. Keller, R. Schibli, B. Wünsch, L. Mu, S. M. Ametamey, J. Nucl. Med. 2019, 60, 259, https://doi.org/10.2967/jnumed.118.212134; e) S. M. Sephton, A. M. Herde, L. Mu, C. Keller, S. Rudisuhli, Y. Auberson, R. Schibli, S. D. Krämer, S. M. Ametamey, Eur. J. Nucl. Med. Mol. Imaging 2015, 42, 128 , https://doi.org/10.1007/s00259-014-2883-7; f) G. Warnock, M. Sommerauer, L. Mu, G. Pla Gonzalez, S. Geistlich, V. Treyer, R. Schibli, A. Buck, S. D. Krämer, S. M. Ametamey, Eur. J. Nucl. Med. Mol. Imaging 2018, 45, 1041, https://doi.org/10.1007/s00259-017-3879-x; g) S. D. Krämer, T. Betzel, L. Mu, A. Haider, A. M. Herde, A. K. Boninsegni, C. Keller, M. Szermerski, R. Schibli, B. Wünsch, S. M. Ametamey, J. Nucl. Med. 2018, 59, 698, https://doi.org/10.2967/jnumed.117.200451

[2] J. Passchier, A. Gee, A. Willemsen, W. Vaalburg, A. van Waarde, Methods 2002, 27, 278, https://doi.org/Pii S1046-2023(02)00084-1.

[3] W. C. Eckelman, C. A. Mathis, Nucl. Med. Biol. 2006, 33, 161, https://doi.org/10.1016/j.nucmedbio.2006.01.010.

[4] V. W. Pike, Trends Pharmacol. Sci. 2009, 30, 431, https://doi.org/10.1016/j.tips.2009.05.005.

[5] R. N. Waterhouse, Mol. Imaging Biol. 2003, 5, 376.

[6] T. Ohe, M. Sato, S. Tanaka, N. Fujino, M. Hata, Y. Shibata, A. Kanatani, T. Fukami, M. Yamazaki, M. Chiba, Y. Ishii, Drug Metab. Dispos. 2003, 31, 1251, https://doi.org/10.1124/dmd.31.10.1251.

[7] a) Y. L. Chen, P. J. Conn, Drugs of the Future 2008, 33, 355 , https://doi.org/10.1358/dof.2008.033.04.1186966; b) L. Zhang, A. Villalobos, E. M. Beck, T. Bocan, T. A. Chappie, L. Chen, S. Grimwood, S. D. Heck, C. J. Helal, X. Hou, J. M. Humphrey, J. Lu, M. B. Skaddan, T. J. McCarthy, P. R. Verhoest, T. T. Wager, K. Zasadny, J. Med. Chem. 2013, 56, 4568, https://doi.org/10.1021/jm400312y; c) L. Zhang, L. Chen, E. M. Beck, T. A. Chappie, R. V. Coelho, S. D. Doran, K. H. Fan, C. J. Helal, J. M. Humphrey, Z. Hughes, K. Kuszpit, E. A. Lachapelle, J. T. Lazzaro, C. Lee, R. J. Mather, N. C. Patel, M. B. Skaddan, S. Sciabola, P. R. Verhoest,

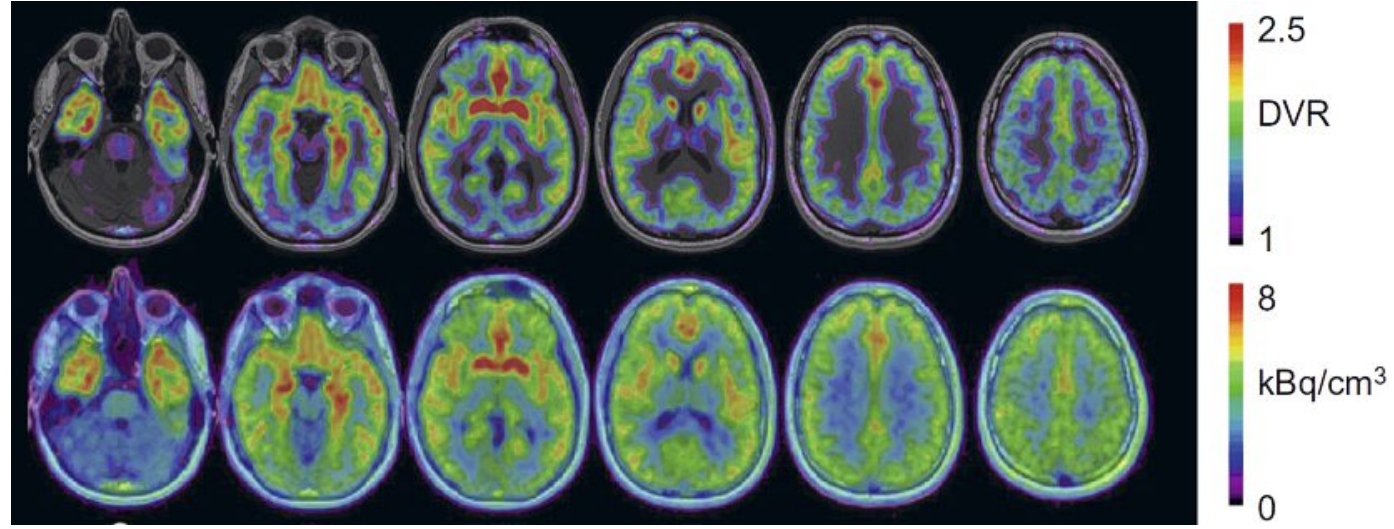

Fig. 6. Representative $\left[{ }^{18} \mathrm{~F}\right] \mathrm{PSS} 232$ scan of a volunteer, superimposed on simultaneously measured T1magnetic resonance image data. From left to right, image planes from superior to inferior. Upper row, voxel-wise DVR with cerebellum as the reference region. Lower row, averaged $\mathrm{kBq} / \mathrm{cm}^{3}$ from $45-$ 90 min after tracer injection, when tracer distribution is in steady state. Adapted from Warnock et al. European Journal of Nuclear Medicine and Molecular Imaging 2018. Reprinted with the permission from Springer Nature and Copyright Clearance Center. 
J. M. Young, K. Zasadny, A. Villalobos, J. Med. Chem. 2017, 60, 8538, https://doi.org/10.1021/acs.jmedchem.7b01050; d) L. Zhang, L. Chen, J. K. Dutra, E. M. Beck, S. Nag, A. Takano, N. Amini, R. Arakawa, M. A. Brodney, L. M. Buzon, S. D. Doran, L. F. Lanyon, T. J. McCarthy, K. R. Bales, C. E. Nolan, B. T. O'Neill, K. Schildknegt, C. Halldin, A. Villalobos, J. Med. Chem. 2018, 61, 3296, https://doi.org/10.1021/acs.jmedchem.7b01769.

[8] a) L. Mu, D. Bieri, R. Slavik, K. Drandarov, A. Müller, S. Cermak, M. Weber, R. Schibli, S. D. Krämer, S. M. Ametamey, J. Neurochem. 2013, 126, 616, https://doi.org/10.1111/jnc.12354; b) L. Mu, A. Müller Herde, P. M. Ruefli, F. Sladojevich, S. Milicevic Sephton, S. D. Krämer, A. J. Thompson, R. Schibli, S. M. Ametamey, M. Lochner, ACS Chem. Neurosci. 2016, 7, 1552, https://doi.org/10.1021/acschemneuro.6b00192.

[9] a) C. Crouzel, B. Langstrom, V. W. Pike, H. H. Coenen, Appl. Radiat. Isotopes 1987, 38, 601; b) K. Dahl, C. Halldin, M. Schou, Clin. Transl. Imaging 2017, 5, 275, https://doi.org/10.1007/s40336-017-0223-1.

[10] D. van der Born, A. Pees, A. J. Poot, R. V. A. Orru, A. D. Windhorst, D. J Vugts, Chem. Soc. Rev. 2017, 46, 4709, https://doi.org/10.1039/c6cs00492j.

[11] a) M. F. Bear, Genes Brain Behav. 2005, 4, 393 https://doi.org/10.1111/j.1601-183X.2005.00135.x; b) F. I. Carroll, Addiction Rev. 2008, 1141, 221, https://doi.org/10.1196/annals.1441.015; c) F. Gasparini, G. Bilbe, B. Gomez-Mancilla, W. Spooren, Curr. Opin. Drug Discov. Develop. 2008, 11, 655; d) M. Pietraszek, J. Nagel, A. Gravius, D. Schafer, W. Danysz, Amino Acids 2007, 32, 173, https://doi.org/10.1007/s00726-006-0319-9; e) W. Spooren, T. Ballard, F. Gasparini, M. Amalric, V. Mutel, R. Schreiber, Behav. Pharmacol. 2003, 14, 257, https://doi.org/10.1097/01.fbp.0000081783.35927.8f.

[12] a) F. Gasparini, K. Lingenhoehl, P. J. Flor, N. Stoehr, C. Stierlin, M. Heinrich, I. Vranesic, H. Allgeier, M. Biollaz, R. Heckendorn, S. Urwyler, M. Schmutz, W. Spooren, M. A. Varney, E. C. Johnson, S. D. Hess, A. Sakaan, E. Santori, G. Velicelebi, R. Kuhn, Neuropharmacol. 1999, 38, 52; b) P. M. Lea, A. I. Faden, CNS Drug Rev. 2006, 12, 149.

[13] a) S. M. Ametamey, L. J. Kessler, M. Honer, M. T. Wyss, A. Buck, S. Hintermann, Y. P. Auberson, F. Gasparini, P. A. Schubiger, J. Nucl. Med. 2006, 47, 698; b) S. M. Ametamey, V. Treyer, J. Streffer, M. T. Wyss, M. Schmidt, M. Blagoev, S. Hintermann, Y. Auberson, F. Gasparini, U. C. Fischer, A. Buck, J. Nucl. Med. 2007, 48, 247.

[14] F. Akkus, S. M. Ametamey, V. Treyer, C. Burger, A. Johayem, D. Umbricht, B. Gomez Mancilla, J. Sovago, A. Buck, G. Hasler, Proc. Natl. Acad. Sci. USA 2013, 110, 737, https://doi.org/10.1073/pnas.1210984110.

[15] a) K. Hefti, S. C. Holst, J. Sovago, V. Bachmann, A. Buck, S. M Ametamey, M. Scheidegger, T. Berthold, B. Gomez-Mancilla, E. Seifritz, H. P. Landolt, Biol. Psychiatry 2013, 73, 161, https://doi.org/10.1016/j.biopsych.2012.07.030; b) S. C. Holst, A. Sousek, K. Hefti, S. Saberi-Moghadam, A. Buck, S. M. Ametamey, M. Scheidegger, P. Franken, A. Henning, E. Seifritz, M. Tafti, H. P. Landolt, Elife 2017, 6, https://doi.org:10.7554/eLife.28751

[16] C. Lucatelli, M. Honer, J. F. Salazar, T. L. Ross, P. A Schubiger, S. M. Ametamey, Nucl. Med. Biol. 2009, 36, 613, https://doi.org/10.1016/j.nucmedbio.2009.03.005.

[17] S. Milicevic Sephton, L. Mu, W. B. Schweizer, R. Schibli, S D. Krämer, S. M. Ametamey, J. Med. Chem. 2012, 55, 7154, https://doi.org/10.1021/jm300648b.

[18] M. Honer, A. Stoffel, L. J. Kessler, P. A. Schubiger, S. M. Ametamey, Nucl. Med. Biol. 2007, 34, 973, https://doi.org/10.1016/j.nucmedbio.2007.07.017.

[19] C. A. Baumann, L. Mu, S. Johannsen, M. Honer, P. A. Schubiger, S. M. Ametamey, J. Med. Chem. 2010, 53, 4009, https://doi.org/10.1021/jm901850k.

[20] C. A. Wanger-Baumann, L. Mu, M. Honer, S. Belli, M. F. Alf, P. A. Schubiger, S. D. Krämer, S. M. Ametamey, Neuroimage 2011, 56, 984, https://doi.org/10.1016/j.neuroimage.2011.03.024.

[21] S. M. Sephton, P. Dennler, D. S. Leutwiler, L. Mu, R. Schibli, S. D. Krämer, S. M. Ametamey, Chimia 2012, 66, 201, https://doi.org/10.2533/chimia.2012.201

[22] A. N. French, E. Napolitano, H. F. VanBrocklin, R. N. Hanson, M. J. Welch, J. A. Katzenellenbogen, Nucl. Med. Biol. 1993, 20, 31.

[23] B. Testa, S. D. Krämer, Chem. Biodivers. 2007, 4, 257, https://doi.org/10.1002/cbdv.200790032.

[24] S. M. Sephton, L. J. Mu, M. Dragic, S. D. Krämer, R. Schibli, S. M. Ametamey, Synthesis 2013, 45, 1877, https://doi.org/10.1055/s-0033-1338843.

[25] A. Müller Herde, R. Schibli, M. Weber, S. M. Ametamey, Eur. J. Nucl. Med. Mol. Imaging 2019, 46, 407, https://doi.org/10.1007/s00259-018-4179-9.

[26] S. F. Traynelis, L. P. Wollmuth, C. J. McBain, F. S. Menniti, K. M. Vance, K. K. Ogden, K. B. Hansen, H. Yuan, S. J. Myers, R. Dingledine, Pharmacol. Rev. 2010, 62, 405, https://doi.org/10.1124/pr.109.002451.
[27] H. Furukawa, S. K. Singh, R. Mancusso, E. Gouaux, Nature 2005, 438, 185 , https://doi.org/10.1038/nature04089.

[28] a) L. Mony, J. N. Kew, M. J. Gunthorpe, P. Paoletti, Br. J. Pharmacol. 2009, 157, 1301, https://doi.org/10.1111/j.1476-5381.2009.00304.x; b) S J. Myers, H. Yuan, J. Q. Kang, F. C. K. Tan, S. F. Traynelis, C. M. Low, F1000Research 2019, 8, https://doi.org/10.12688/f1000research.18949.1; c) W. Liu, X. Jiang, Y. Zu, Y. Yang, Y. Liu, X. Sun, Z. Xu, H. Ding, Q. Zhao, Eur. J. Med. Chem. 2020, 200, 112447, https://doi.org/10.1016/j.ejmech.2020.112447; d) S. Qiu, X. Y. Li, M. Zhuo, Sem. Cell Devel. Biol. 2011, 22, 521, https://doi.org/10.1016/j.semcdb.2011.06.003.

[29] a) T. Fuchigami, M. Nakayama, S. Yoshida, TheScientificWorldJournal 2015, 716514, https://doi.org/10.1155/2015/716514; b) J. A. Christiaans, P. J. Klein, A. Metaxas, E. J. Kooijman, R. C. Schuit, J. E. Leysen, A. A Lammertsma, B. N. van Berckel, A. D. Windhorst, Nucl. Med. Biol. 2014, 41, 670, https://doi.org/10.1016/j.nucmedbio.2014.04.131; c) R. Koudih, G. Gilbert, M. Dhilly, A. Abbas, L. Barre, D. Debruyne, F. Sobrio, Org. Biomol. Chem. 2012, 10, 8493, https://doi.org/10.1039/c2ob26378e; d) R. Koudih, G. Gilbert, M. Dhilly, A. Abbas, L. Barre, D. Debruyne, F. Sobrio, Eur. J. Med. Chem. 2012, 53, 408, https://doi.org/10.1016/j.ejmech.2012.04.011; e) R. Labas, G. Gilbert, O. Nicole, M. Dhilly, A. Abbas, O. Tirel, A. Buisson, J. Henry, L. Barré, D. Debruyne, F. Sobrio, Eur. J. Med. Chem. 2011, 46, 2295 , https://doi.org/10.1016/j.ejmech.2011.03.013; f) E. Arstad, S. Platzer, A. Berthele, L. S. Pilowsky, S. K. Luthra, H. J. Wester, G. Henriksen, Bioorg. Med. Chem. 2006, 14, 6307, https://doi.org/10.1016/j.bmc.2006.05.046; g) F. Dollé, H. Valette, S. Demphel, C. Coulon, M. Ottaviani, M. Bottlaender, M. Kassiou, J. Label. Compds Radiopharmaceut. 2004, 47, 911, https://doi.org/10.1002/jlcr.877; h) G. Roger, B. Lagnel, L. Besret, Y. Bramoulle, C. Coulon, M. Ottaviani, M. Kassiou, M Bottlaender, H. Valette, F. Dolle, Bioorg. Med. Chem. 2003, 11, 5401, https://doi.org/10.1016/j.bmc.2003.09.036; i) G. Roger, F. Dolle, B. De Bruin, X. Liu, L. Besret, Y. Bramoulle, C. Coulon, M. Ottaviani, M Bottlaender, H. Valette, M. Kassiou, Bioorg. Med. Chem. 2004, 12, 3229 , https://doi.org/10.1016/j.bmc.2004.03.065; j) T. Haradahira, J. Maeda, T. Okauchi, M. R. Zhang, J. Hojo, T. Kida, T. Arai, F. Yamamoto, S. Sasaki, M. Maeda, K. Suzuki, T. Suhara, Nucl. Med. Biol. 2002, 29, 517.

[30] a) B. Tewes, B. Frehland, D. Schepmann, K. U. Schmidtke, T. Winckler, B. Wünsch, ChemMedChem 2010, 5, 687, https://doi.org/10.1002/cmdc.201000005; b) B. Tewes, B. Frehland, D. Schepmann, K. U. Schmidtke, T. Winckler, B. Wünsch, Bioorg. Med. Chem. 2010, 18, 8005, https://doi.org/10.1016/j.bmc.2010.09.026; c) S. Gawaskar, D. Schepmann, A. Bonifazi, B. Wünsch, Bioorg. Med. Chem. 2014, 22, 6638, https://doi.org/10.1016/j.bmc.2014.10.004.

[31] a) P. C. Contreras, M. E. Bremer, N. M. Gray, Neurosci. Lett. 1990, 116, 190; b) T. Maurice, T. P. Su, Pharmacol. Ther. 2009, 124, 195, https://doi.org/10.1016/j.pharmthera.2009.07.001.

[32] S. M. Ametamey, M. Honer, P. A. Schubiger, Chem. Rev. 2008, 108, 1501, https://doi.org/10.1021/cr0782426.

[33] S. Preshlock, S. Calderwood, S. Verhoog, M. Tredwell, M. Huiban, A. Hienzsch, S. Gruber, T. C. Wilson, N. J. Taylor, T. Cailly, M. Schedler, T. L. Collier, J. Passchier, R. Smits, J. Mollitor, A. Hoepping, M. Müller, C. Genicot, J. Mercier, V. Gouverneur, Chem. Commun. 2016, 52, 8361, https://doi.org/10.1039/C6CC03295H.

[34] a) M. Zheng, H. Ahmed, K. Smart, Y. Xu, D. Holden, M. Kapinos, Z. Felchner, J. Ropchan, G. Tamagnan, R. Carson, Y. Huang, S. Ametamey, J. Nucl. Med. 2020, 61, 265; b) H. Ahmed, M.-Q. Zheng, K. Smart, D. Holden, Y. Xu, L. Zhang, P. Emery, J. Ropchan, G. Tamagnan, R. Carson, S Ametamey, Y. Huang, J. Nucl. Med. 2020, 61, 263.

[35] A. Müller Herde, C. Keller, S. Milicevic Sephton, L. Mu, R. Schibli, S. M. Ametamey, S. D. Krämer, J. Neurochem. 2015, 133, 330, https://doi.org/10.1111/jnc.13001.

\section{License and Terms}



This is an Open Access article under the terms of the Creative Commons Attribution License CC BY_NC 4.0. The material may not be used for commercial purposes.

The license is subject to the CHIMIA terms and conditions: (http:// chimia.ch/component/sppagebuilder/?view=page \&id=12).

The definitive version of this article is the electronic one that can be found at https://doi.org/10.2533/chimia.2020.960 